\title{
Effect of biomass burning on marine stratocumulus clouds off the California coast
}

\author{
J. Brioude ${ }^{1,2}$, O. R. Cooper ${ }^{1,2}$, G. Feingold ${ }^{2}$, M. Trainer ${ }^{2}$, S. R. Freitas ${ }^{3}$, D. Kowal ${ }^{4}$, J.K. Ayers ${ }^{5}$, E. Prins ${ }^{6}$, P. Minnis ${ }^{7}$, \\ S. A. McKeen ${ }^{1,2}$, G. J. Frost ${ }^{1,2}$, and E.-Y. Hsie ${ }^{1,2}$ \\ ${ }^{1}$ Cooperative Institute for Research in Environmental Sciences, University of Colorado, Boulder, Colorado, USA \\ ${ }^{2}$ Chemical Sciences Division, Earth System Research Lab., NOAA, Boulder, Colorado, USA \\ ${ }^{3}$ Center for Weather Forecasting and Climate Studies, INPE, Cachoeira Paulista, Brazil \\ ${ }^{4}$ National Geophysical Data Center, NESDIS, NOAA, USA \\ ${ }^{5}$ Science Systems and Applications Incorporated, Hampton Virginia, USA \\ ${ }^{6}$ UW-Madison SSEC/CIMSS - Consultant, Grass Valley, CA, USA \\ ${ }^{7}$ NASA Langley Research Center, Hampton, Virginia, USA
}

Received: 29 May 2009 - Published in Atmos. Chem. Phys. Discuss.: 3 July 2009

Revised: 27 September 2009 - Accepted: 12 November 2009 - Published: 23 November 2009

\begin{abstract}
Aerosol-cloud interactions are considered to be one of the most important and least known forcings in the climate system. Biomass burning aerosols are of special interest due to their radiative impact (direct and indirect effect) and their potential to increase in the future due to climate change. Combining data from Geostationary Operational Environmental Satellite (GOES) and MODerate-resolution Imaging Spectroradiometer (MODIS) with passive tracers from the FLEXPART Lagrangian Particle Dispersion Model, the impact of biomass burning aerosols on marine stratocumulus clouds has been examined in June and July of 2006-2008 off the California coast. Using a continental tracer, the indirect effect of biomass burning aerosols has been isolated by comparing the average cloud fraction and cloud albedo for different meteorological situations, and for clean versus polluted (in terms of biomass burning) continental air masses at 14:00 local time. Within a $500 \mathrm{~km}$-wide band along the coast of California, biomass burning aerosols, which tend to reside above the marine boundary layer, increased the cloud fraction by 0.143 , and the cloud albedo by 0.038 . Absorbing aerosols located above the marine boundary layer lead to an increase of the lower tropospheric stability and a reduction in the vertical entrainment of dry air from above, leading to increased cloud formation. The combined effect was an indirect radiative forcing of $-7.5 \% \pm 1.7 \%$ (cooling effect) of the outgoing radiative flux at the top of the atmosphere on average, with a bias due to meteorology of $+0.9 \%$. Further
\end{abstract}

Correspondence to: J. Brioude

(jerome.brioude@noaa.gov) away from the coast, the biomass burning aerosols, which were located within the boundary layer, reduced the cloud fraction by 0.023 and the cloud albedo by 0.006 , resulting in an indirect radiative forcing of $+1.3 \% \pm 0.3 \%$ (warming effect) with a bias of $+0.5 \%$. These results underscore the dual role that absorbing aerosols play in cloud radiative forcing.

\section{Introduction}

Aerosol-cloud interactions are considered to be one of the most important and least known forcings in the climate system (IPCC, 2007). Some aerosols act as cloud condensation nuclei, determining the cloud droplet number concentration, and modifying cloud optical properties by increasing cloud albedo (first indirect effect). Contradictory results have been found regarding their impact on cloud lifetime (Rosenfeld and Woodley, 1999; Khain et al., 2001; Jiang et al., 2006) and precipitation (Andreae et al., 2004; Koren et al., 2005; Jin et al., 2005; Rosenfeld, 2005) (second indirect effect).

Due to their radiative impact on the Earth's energy budget and the possibility that their global mean burden will increase in the future (Westerling et al., 2006), biomass burning (BB) aerosols are receiving increased attention regarding their impact on climate change. Depending on the nature of the burned biomass and the burning conditions, BB aerosols have varying capacities for absorbing and reflecting incident solar radiation (direct effect). According to the IPCC (2007), BB aerosols have a direct radiative forcing of $+0.03 \pm 0.12 \mathrm{Wm}^{-2}$ globally. 
Converting visible light to thermal energy, absorbing aerosols can warm air masses and increase static stability, or reduce relative humidity. Therefore, they induce an increase or a reduction of cloud cover and cloud albedo, depending on the vertical distribution of the aerosols within or above the clouds (semi-direct effect; Johnson et al., 2004; Feingold et al., 2005), and reduce rainfall (Hoffman et al., 2002; Freitas et al., 2005).

Using a global circulation model, Lohmann and Feichter (2001) compared the magnitude of all these competing effects and found that the semi-direct effect can be important locally, despite the fact that indirect effects dominate globally.

Published results on the indirect effect emphasize both positive or negative impacts on cloud cover and cloud albedo, depending on aerosol type, aerosol vertical distribution relative to the cloud, and the natural variability of cloud properties. A better understanding requires techniques that can combine accurate aerosol and cloud property parameters over an extended period of time to distinguish the impact of aerosols from the natural cloud variability.

Marine stratocumulus clouds are known to be an important factor in the climate system (Medeiros et al., 2008). On average, they cover about $29 \%$ of the globe annually (Klein and Hartmann, 1993). They reflect much more sunlight than the underlying ocean, and radiate at nearly the same temperature as the ocean surface. Their net radiative impact is a cooling of the Earth system. They commonly form off the western continental coasts where upwelling water reduces the ocean temperature. There, lower surface temperatures and strong subsidence induce a shallow inversion layer, confining the marine stratocumulus clouds to roughly the first kilometer of the atmosphere. It has been estimated that these clouds affect the net radiative balance by $-1 \mathrm{Wm}^{-2}$ per percent cloudiness in these regions (Klein and Hartmann, 1993).

These clouds are very sensitive to changes in aerosol concentration, especially in stratiform cloud regions west of California (Platnick and Twomey, 1993). The semi-direct effect can significantly influence their radiative forcing (e.g. Johnson et al., 2004) and may have a significant role in the climate system.

Studies based on large eddy simulations (LES) have addressed the aerosol indirect effect on marine stratocumulus (Feingold et al., 1994; Kogan et al., 1995; Lu and Seinfeld, 2005; Bretherton et al., 2007). Those studies are useful for understanding the underlying mechanisms involved in aerosol cloud interactions, and thus reduce some of the uncertainty in the estimation of the aerosol indirect effect. However, they have only been applied to idealized cases, using parameters retrieved from in-situ measurements during field intensives. LES cannot be used to build a climatology of the aerosol indirect effect.

In contrast, satellite based studies are directly applied to real cases, and can be used to study the aerosol indirect effect over a long time period and a large area (e.g. Kaufman et al., 2005; Jensen et al., 2008). But satellite-based studies are known to suffer from retrieval bias. In cloudy pixels, the aerosol concentration integrated over the total column (aerosol optical depth, AOD) is unknown. Typically, an assumption is made that aerosol concentration is horizontally homogeneous between cloudy and clear sky regions. This hypothesis cannot be applied to marine stratocumulus clouds which can cover a large region without any breaks in clouds to allow remote sensing of the aerosols. Furthermore, the AOD retrieved near clouds can be affected by meteorological bias. For instance, Mauger et al. (2007) have shown that both AOD and cloud fraction are correlated with static stability. Another weakness is due to the fact that the aerosol vertical distribution is usually unknown, while it is a key component of the aerosol indirect effect (Johnson et al., 2004).

Previous studies (Schwartz et al., 2002; Chameides et al., 2002) have used column-integrated anthropogenic aerosol burden from chemical transport models with satellite derived cloud products to study anthropogenic aerosol indirect effects. In those studies, aerosol and cloud products were independently derived.

To remove the aerosol bias from satellite retrievals, and to improve quantification of the aerosol vertical distribution, Avey et al. (2007) combined satellite cloud products with aerosol tracers from the FLEXPART Lagrangian particle dispersion model. They were able to diagnose the collocation of clouds and aerosols because of the high vertical resolution of the model. By using passive tracers, they also discarded any feedback from cloud on aerosols, and thus worked with independent parameters (passive tracer and clouds). They found that cloud droplet effective radius was smaller and cloud optical depth greater when the model indicated that polluted air masses were collocated with clouds.

In this paper, satellite products from the MODerateresolution Imaging Spectroradiometer (MODIS) and the imager on the Geostationary Operational Environmental Satellite located at $135^{\circ} \mathrm{W}$ (GOES-WEST) are combined with FLEXPART to improve our understanding of (1) how BB aerosols affect the cloud fraction and cloud albedo of marine stratocumulus clouds west of California, and (2) the radiative forcing due to BB aerosols.

As shown by previous studies, marine stratocumulus clouds are sensitive to the aerosol indirect effect. Anthropogenic aerosols impact marine clouds with offshore flow. However, it is difficult to assess the impact of continental air masses, which contain anthropogenic aerosols, on clouds adjacent to polluted regions because the impact of these air masses before humans modified them is unknown.

While the emission rates of anthropogenic and biogenic aerosols are fairly constant over a season, BB aerosol emissions are highly variable. The frequency and intensity of fires vary from year to year and throughout seasons. Thus for a particular offshore transport pattern, one can expect to have different $\mathrm{BB}$ aerosol concentrations for different days and different years. This variability allows us to study the 
$\mathrm{BB}$ aerosol semi-direct and indirect effect by reducing external effects (meteorology or anthropogenic aerosols).

Biomass burning and anthropogenic passive tracers are simulated with FLEXPART. In addition, a passive surface tracer (called the continental tracer) is also advected through the model. It has a constant emission rate over the continent. Its purpose is to trace transport pathways from the continent toward the ocean regardless of anthropogenic emissions, and it allows us to segregate marine air from continental air. This is very important because the weather conditions that transport continental air across the eastern Pacific affect cloud formation differently from marine air masses. To our knowledge, this is the first time that such a continental tracer is used to study the aerosol indirect effect by comparing cloud properties for conditions with and without BB aerosols, but when the study region is influenced by continental air masses.

California is an ideal region to assess the impact of BB aerosols on marine stratocumulus clouds. The marine stratocumulus clouds are common during summer in the Eastern North Pacific Ocean, with a maximum in June (Klein and Hartmann, 1993). California is also a region known for its numerous wild fires (Westerling et al., 2006). Large wildfires occurred earlier in the summer of 2008 compared to 2006 and 2007, providing significant interannual variability. Satellite data and model output are analysed for June and July of those 3 years, focusing on 14:00 local time, when solar insolation is high and the aerosol indirect effect is expected to be active. Section 2 presents the modeling methods and satellite products. Section 3 presents the vertical distribution of BB plumes using a plume rise module. Sections 4 and 5 present the impact of the indirect and semi-direct effect of BB aerosols, respectively. In Sect. 6, the indirect radiative forcing due to BB aerosols is discussed. Finally, conclusions are drawn in Sect. 7.

\section{Method}

\subsection{Modeling}

To simulate air pollution transport, version 6.2 of the FLEXPART Lagrangian particle dispersion model (Stohl et al., 2005 and references therein) is used. This model has been used to successfully simulate the transport of anthropogenic emissions or BB plumes (Stohl et al., 2007; Brioude et al., 2007; Warneke et al., 2009).

FLEXPART was driven by meteorological data from the National Centers for Environmental Prediction (NCEP) Global Forecast System (GFS) with a temporal resolution of $3 \mathrm{~h}$ (analyses at 00:00, 06:00, 12:00, 18:00 UTC; 3-h forecasts at 03:00, 09:00, 15:00, 21:00 UTC), and 26 vertical levels. Horizontal resolution was $0.5 \times 0.5$ degrees globally for the 2008 dataset, and $1 \times 1$ degree globally for the 2006 and 2007 datasets. Millions of particles in FLEXPART were transported both by the resolved GFS winds and parame- terized subgrid motions. FLEXPART parameterizes turbulence in the boundary layer by solving Langevin equations for Gaussian turbulence (Stohl and Thomson, 1999). BL heights are calculated using a combined Richardson number and lifting parcel technique (Vogelezang and Holtslag, 1996). FLEXPART also has a parameterization scheme for convection (Forster et al., 2007). The horizontal resolution of the FLEXPART output domain was $0.15 \times 0.15$ degrees, with 13 levels between 0 and $10 \mathrm{~km}$ with a vertical resolution of $150 \mathrm{~m}$ in the first $600 \mathrm{~m}, 200 \mathrm{~m}$ up to $1000 \mathrm{~m}$, and $300 \mathrm{~m}$ up to $1600 \mathrm{~m}$.

An anthropogenic aerosol tracer was computed, based on anthropogenic CO emissions from the EPA 1999 National Emission Inventory at $44 \mathrm{~km}$ resolution (Frost et al., 2006). Injection heights of point sources in the model are specified in the inventory, while the mean injection height of area sources was between 0 and $20 \mathrm{~m}$. We will use MODISderived aerosol mass concentration in Sect. 4.1 to convert the anthropogenic $\mathrm{CO}$ tracer into an anthropogenic aerosol mass concentration.

Because the aerosol-cloud interaction is sensitive to the aerosol vertical distribution, it is necessary to have a realistic BB injection height for each fire. A fixed injection height would over- or underestimate the aerosol concentration within the continental boundary layer. To address this issue, the plume rise module described by Freitas et al. (2007) is used to calculate the injection height of each fire. The size and fire radiative power (FRP) of each fire are retrieved from the Wildfire Automated Biomass Burning Algorithm (WF_ABBA; Prins et al., 1998). The sensible heat flux released by the fires is calculated assuming that the radiative fraction of the total fire energy released was approximately 10\% (Wooster et al., 2005; Freeborn et al., 2008). The vertical profiles of temperature and humidity are retrieved from the NCEP GFS profiles interpolated linearly in space and time. To calculate the black carbon emission, the formula from Seiler and Crutzen (1980), based on emission factors and area burned is used. The emission factor of particle matter PM2.5 from Wiedinmyer et al. (2006) is used as a proxy of aerosol emission. The area burned is assumed to be linearly correlated with the size of the GOES hot spots. The BB in 2006, 2007 and 2008 was mainly from forest (60\%), grassland (22\%), shrubland (7\%) and cropland (4\%).

Average FRP and fire size are compiled per land use type and per hour to fill in missing data when fire hotspots are detected but contamination in the pixel prevents the algorithm from accurately calculating the size and FRP. The fire detections with low confidence are removed from the analysis. Continuous emissions are assumed when 2 hot spots were detected in the same $8 \times 8 \mathrm{~km}^{2}$ area within $6 \mathrm{~h}$. The missing fire size and FRP are filled in with the average values explained above. Rather than calculating a single injection height for each fire, we computed an injection height probability density function (PDF). Because the sensible heat flux is considered to be the most uncertain parameter in the plume rise 
module, 11 different sensible heat flux values (ranging from $10 \%$ to $110 \%$ of its initial value) were applied in the plume rise module for each fire. The particles are released randomly according to the obtained vertical PDF. Even though uncertainties can arise from the heat flux, the size of the fire and the injection height module itself, the final injection height is mainly influenced by the stability of the atmosphere, as shown by Kahn et al. (2007).

In conjunction with the BB tracer, a continental tracer has been used in this study to represent the transport pattern of continental air masses over the ocean. This passive tracer has a constant emission rate at all locations over western North America, between $131^{\circ} \mathrm{W}$ and $90^{\circ} \mathrm{W}$. It is released between the surface and $150 \mathrm{~m}$.

The BB aerosol, anthropogenic and continental tracers are passive. They don't undergo wet or dry deposition. This limitation can reduce the validity of the tracer products under precipitating conditions. However, an ageclass of 5 days is used for the anthropogenic and BB aerosol tracers, which is roughly the $\mathrm{CCN}$ lifetime in clouds (Twomey and Wojciehowski, 1969; Avey et al., 2007). An ageclass is defined as the time elapsed since the particles were released. A passive tracer with an ageclass of 5 days means that the age of a given passive tracer ranges between 0 and 5 days. According to the monthly rainfall detected by the Tropical Rainfall Measuring Mission (TRMM, url: http://trmm.gsfc.nasa. gov/trmm_rain/Events/trmm_climatology_3B43.html) satellite, the precipitation from marine clouds west of California is negligible. Little impact from precipitation is expected as marine stratocumulus clouds are generaly associated with either no precipitation or drizzle in California during summertime, except when rift areas (areas of broken stratocumulus) pass through the domain. These areas are typically characterized by pristine marine air, large droplet sizes, an open cellular structure, and drizzle (e.g., Sharon et al., 2006).

\subsection{Satellite products}

Cloud fraction was calculated with two methods. In the first method, we used the 4-km infrared (10.9 micrometers) and low altitude water vapor (3.9 micrometers) channels from the imager on the GOES-WEST satellite, and applied the algorithm of Jedlovec and Laws (2003). In the second method, we detected low level clouds using the $1 \mathrm{~km}$ visible channel from GOES and a spatial coherence method compared to a cloud-free surface reflectance calculated over 20 days by selecting the darkest pixels to detect low level clouds. Then the cloud cover was averaged over $0.15 \times 0.15 \mathrm{deg}$ grid cells to provide the cloud fraction. Based on the infrared channel, grid cells with high clouds are removed. These two techniques provide similar results, with the differences presented in the discussion section.

We used the GOES shortwave broadband albedo, droplet effective radius, liquid water path, and optical depth data from the near-real time cloud products described by Min- nis et al. (2004; available at url: http://www-angler.larc.nasa. gov/). Those products were derived using the methods of Minnis et al. (2009) and are available at a nominal resolution of $8 \mathrm{~km}$, and averaged onto the same $0.15 \times 0.15 \mathrm{deg}$ grid as used for the cloud fractions. The GOES visible channel was calibrated each month against the Terra MODIS 0.64- $\mu \mathrm{m}$ channel as described by Minnis et al. (2002). The GOES products used in this study are valid at 14:00 local time (22:00 h UTC). The MODIS level-3 Cloud Condensation Nuclei and Aerosol Mass Concentration products (Remer et al., 2005) were used to assess the validity of the calculation of $\mathrm{BB}$ aerosols, and to convert the arbitrary model concentrations of $\mathrm{BB}$, anthropogenic and continental tracer into realistic aerosol mass concentrations. Those MODIS satellite products are available at roughly 12:00 local time (20:00 h UTC) over the region.

\section{Vertical distribution of biomass burning plumes}

The vertical injection height distribution relative to the boundary layer height (from FLEXPART) in 2008 (Fig. 1a) has a mode at the top of the boundary layer. About $70 \%$ of the BB plumes remains in the BL, and $30 \%$ is injected above. The distribution is consistent with the satellite based results from Kahn et al. (2008) over the Alaska-Yukon region during summer 2004. It is evident that the injection height is influenced by the static stability of the atmosphere, as shown by Kahn et al. (2007). The BB plumes are typically trapped at the bottom of the first stable layer encountered in the atmosphere, which is on average colocated with the top of the boundary layer. The fires occured mainly in the California Central Valley, the Los Angeles basin and in the Sierra Madre mountains (Fig. 1b). On average, BB aerosols were located over the Eastern North Pacific Ocean 60\% of the time in 2006 and 2008, and 39\% of the time in 2007 for June and July.

Figure 1c presents the average vertical mass distribution of BB tracer over the Central Valley in California. The mass concentration unit of the BB tracer is arbitrary at this stage. We will use the MODIS aerosol mass concentration in the next section to calibrate it. The mass of $\mathrm{BB}$ aerosols is at a maximum near the surface and decreases slowly with height in the boundary layer, and more rapidly above. This average distribution is different from the injection height distribution because the transport over the continent tends to homogenize the tracer in the boundary layer over 5 days.

Offshore and near the coast (Fig. 1d), the average vertical mass distribution is different than inland, with the maximum located above the marine boundary layer (MBL) in a layer about $500 \mathrm{~m}$ thick. Along the California coast, upwelling decreases the sea surface temperature, strengthening the temperature inversion and making the MBL shallower compared to the MBL further offshore (away from the upwelling). The temperature in the MBL is lower than above. Mixing of free tropospheric $\mathrm{BB}$ aerosols down into the MBL is inefficient 


\section{Injection height of BB plumes}
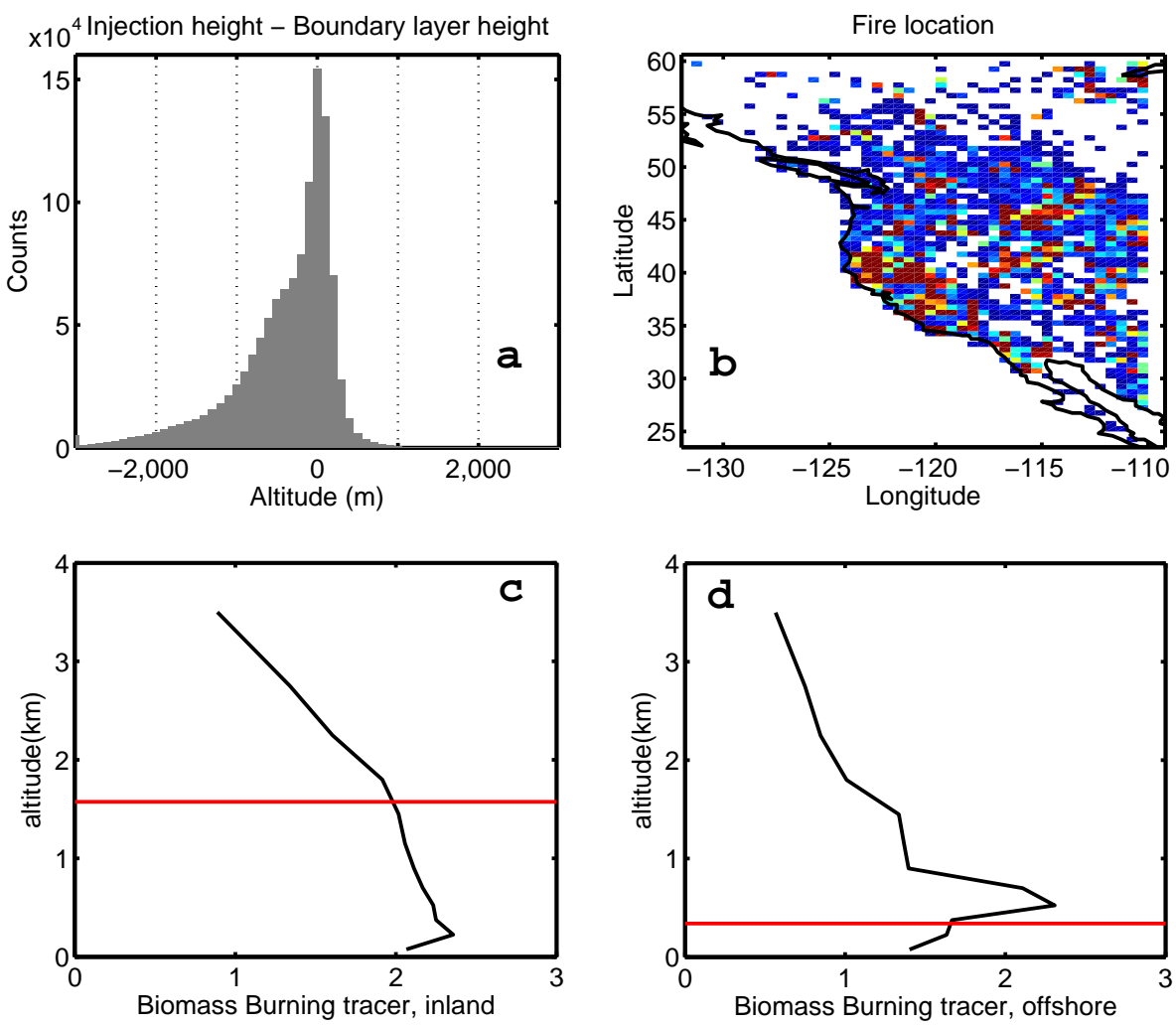

Fig. 1. (a) Distribution of the injection height of BB plumes relatively to the boundary layer height (in 2008). (b) Location of the detected fires in June and July of 2006-2008 (the colorscale from blue to red represents the fire frequency from lowest to highest). Vertical distribution inland (c) and offshore (d) of the mass of FLEXPART biomass burning tracer (arbitrary unit).

because of the stable layer. Owing to the large scale subsidence in this region and the strong static stability, the BB layer is trapped above the inversion layer offshore. Further offshore (more than $1000 \mathrm{~km}$ from the coast), the BB tracer is more dilute, and has a more uniform vertical distribution inside and above the MBL (not shown).

This offshore vertical distribution can potentially increase the temperature of the atmosphere above the MBL via the so called semi-direct effect of absorbing aerosols. According to previous studies (Johnson et al., 2004), this effect can reduce the vertical entrainment of dry air from above, and increase the LWP and the cloud albedo.

\section{Indirect effect of biomass burning aerosol}

\subsection{Biomass burning concentration}

To study the indirect effect from BB aerosols, we first used the MODIS aerosol mass concentration product over the ocean to convert the arbitrary mass of tracer released by the model to realistic mass concentration values. A particle density of $1.5 \mathrm{~g} \mathrm{~cm}^{-3}$ is assumed (e.g. Treffeisen et al., 2007).
The MODIS aerosol mass concentration product is integrated over the total column.

Figure 2 presents the dependence of the MODIS total column aerosol mass concentration on the arbitrary total column mass concentration of the different FLEXPART tracers. We averaged over the column values of the FLEXPART passive tracers at 20:00 h UTC, which is roughly the overpass time of Terra in this region, to the same grid as the MODIS products.

For each tracer (Fig. 2a, b, and c), the functions (colored lines) which best match the relationship between calculated and measured total column mass (black lines) are calculated using a least squares fitting method. We first calculated the relationship between MODIS aerosol mass concentration with the continental and anthropogenic tracer when there is no BB aerosol.

Then the relationship between MODIS aerosol mass concentration and $\mathrm{BB}$ tracer is calculated by removing the contributions from the continental and anthropogenic tracers on MODIS aerosol mass concentration. An aerosol mass concentration background is subtracted from the MODIS mass concentration so that the estimated FLEXPART mass concentration is equal to zero when the arbitrary FLEXPART 


\section{Aerosol mass concentration}
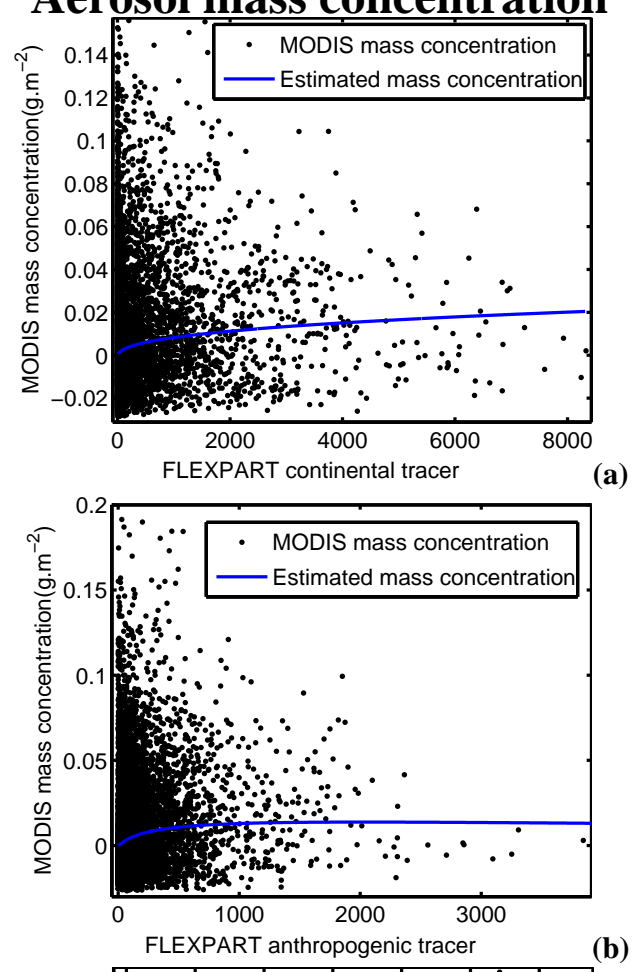

(a)
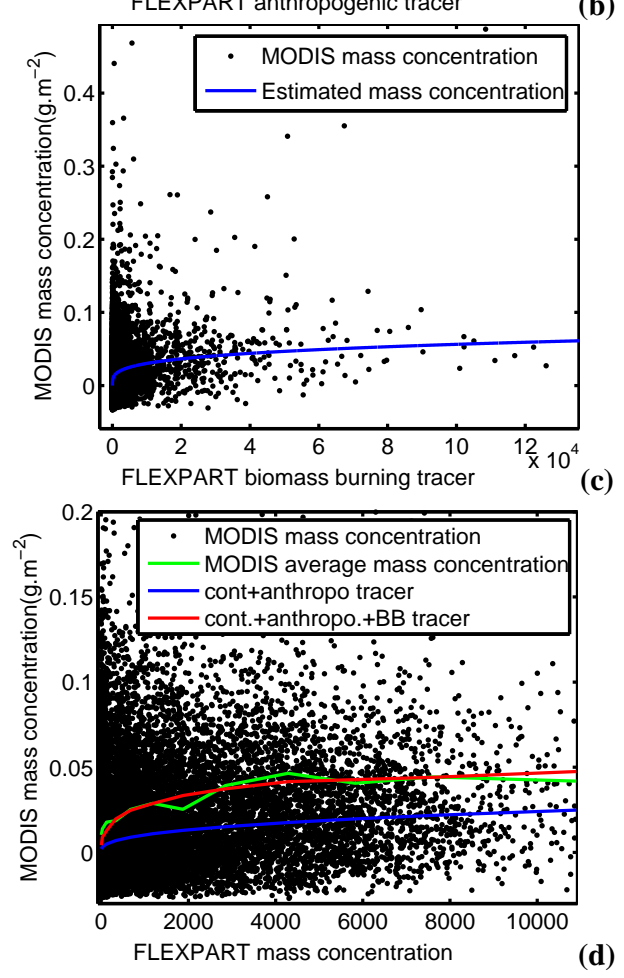

Fig. 2. Relationships between MODIS total column aerosol mass concentration and total column mass of FLEXPART continental, anthropogenic and biomass burning tracers over the ocean. For each tracer, an aerosol mass concentration background is subtracted. mass concentration is zero, explaining the negative MODIS mass concentrations. For each tracer, the relationship has a large standard deviation compared to the mean due to the MODIS aerosol retrieval inaccuracy, the inaccuracy of the transport of FLEXPART passive tracers, and the size of the grid over which the relationships are calculated. However, the relative standard error of the mean ranges between 2 and $10 \%$ and thus the mean is statistically meaningful.

The distribution has more scatter for the continental and anthropogenic tracer than for the $\mathrm{BB}$ tracer. This is probably because the continental and anthropogenic tracers include several types of aerosol sources, while the BB tracer is more exclusive.

Figure $2 \mathrm{~d}$ represents the relationship between the MODIS total column mass with the FLEXPART total column mass. By adding the total column mass of the 3 different tracers, the FLEXPART total column mass (red curve) matches the average MODIS total column mass (green curve).

\subsection{First indirect effect}

It has been shown (Twomey, 1977; Platnick and Twomey, 1993), that an increase of the number of aerosol particles results in an increase of cloud optical depth and a decrease in effective radius at constant liquid water content. This socalled Twomey effect is an important factor in cloud-aerosol interactions because it modifies the cloud albedo.

The daily MODIS cloud products include an integrated column CCN product. Figure 3 a presents the relationship between the MODIS total column CCN and the FLEXPART $\mathrm{BB}$ concentration, showing that the $\mathrm{CCN}$ increases linearly with the BB aerosol number concentration. The relative standard error of the mean ranges between 11 and $20 \%$. It confirms here the potential indirect effect of BB aerosols.

An Indirect Effect (IE) index has been proposed by Feingold et al. (2003) to represent the effect of aerosols on cloud microphysics:

$\mathrm{IE}=\left(\frac{\partial \ln \tau_{c}}{\partial \ln \alpha}\right)_{\mathrm{LWP}}=\left(-\frac{\partial \ln R_{e}}{\partial \ln \alpha}\right)_{\mathrm{LWP}}$

$\tau_{c}$ denotes the cloud optical depth, $R_{e}$ the effective radius, and $\alpha$ the aerosol concentration. The IE values range between 0 and 0.33 (Feingold et al., 2001). The higher the IE value, the higher the relative change in cloud microphysics for a relative change in aerosol concentration.

To conduct such a study, the data are sorted by liquid water path (measured by GOES). We used the GOES satellite products and FLEXPART output valid at 14:00 UTC, when the aerosol indirect effect is expected to be active. For $\alpha$, the average $\mathrm{BB}$ tracer concentration in the marine boundary layer is used. The IE values are calculated when the anthropogenic tracer is low. Figure 3 shows the relationship between BB aerosol tracer and (b) GOES $\tau_{c}$ and (c) GOES $R_{e}$ for different liquid water path bins. The blue lines represent the power-law functions that match the different 
Table 1. Cloud fraction, cloud albedo differences and radiative impact due to the presence of biomass burning aerosols within a $500 \mathrm{~km}-\mathrm{wide}$ band along the coast and further away from the coast using the continental tracer to subdivide the data, using high continental tracer load only, and using the anthropogenic tracer.

\begin{tabular}{cccc}
\hline & $\begin{array}{c}\text { subdivisions using } \\
\text { continental tracer }\end{array}$ & $\begin{array}{c}\text { subdivisions using } \\
\text { high continental tracer }\end{array}$ & $\begin{array}{c}\text { subdivisions using } \\
\text { anthropogenic tracer }\end{array}$ \\
\hline & In a $500 \mathrm{~km}$-wide band along the coast & \\
\hline cloud fraction difference & +0.143 & +0.153 & +0.138 \\
cloud albedo difference & +0.038 & +0.038 & +0.032 \\
Radiative impact $(\%)$ & -7.5 & -7.8 & -6.9 \\
\hline & Further away from the coast & -0.038 \\
\hline cloud fraction difference & -0.023 & -0.018 & -0.008 \\
cloud albedo difference & -0.006 & -0.005 & +1.7 \\
Radiative impact $(\%)$ & +1.3 & +0.8 & \\
\hline
\end{tabular}

distributions using a least squares fitting method. The IE values obtained from those two independent methods are in good agreement. The IE values range from 0.022 for very low LWP (about $40 \mathrm{~g} \mathrm{~m}^{-2}$ ) to 0.040 at higher LWP (between 80 and $120 \mathrm{~g} \mathrm{~m}^{-2}$ ). This range of values is lower than previous observations (between 0.02 and 0.17 , McComiskey et al., 2009; Feingold et al., 2003), probably because of the low hygroscopicity of the BB aerosols. Another possibility is the fact that we calculate aerosol and cloud relationships within $0.15 \times 0.15$ degree grid cells, while correlations between aerosol and cloud are reduced at increasingly larger scales (McComiskey et al., 2009). Those correlations can be reduced further by the uncertainties in the model.

The dependency of IE on LWP for LWP values ranging from 40 to $80 \mathrm{~g} \mathrm{~m}^{-2}$ could arise for many reasons. In some cases of low LWP, the clouds are broken or scattered and $R_{e}$ is likely overestimated while $\tau_{c}$ may be too small (Kato et al., 2006). It is also possible that the extinction from BB aerosols above the cloud could affect the retrieval of $\tau_{c}$ and $R_{e}$ from satellite (Haywood et al., 2003; Wilcox et al., 2009) by reducing the reflectance at several wavelengths, especially for thin clouds. Another possibility is that the sensitivity of the cloud albedo to an increase in CCN (the cloud susceptibility) increases with the albedo, and reaches a maximum for an albedo of 0.5 (Platnick and Twomey, 1993). In this case, the susceptibility of the cloud albedo is higher at a LWP of $80 \mathrm{~g} \mathrm{~m}^{-2}$ than at $40 \mathrm{~g} \mathrm{~m}^{-2}$, because the average cloud albedos are 0.42 and 0.30 , respectively.

The IE values obtained for the indirect effect of BB aerosols are in agreement with previous satellite studies (e.g. 0.085 over the oceans and 0.04 over land from Bréon et al., 2002). These results demonstrate that the first indirect effect from $\mathrm{BB}$ aerosols can be detected in this region. The results also show that modeled $\mathrm{BB}$ aerosol concentrations can be applied to study the overall impact of $\mathrm{BB}$ aerosols on marine stratocumulus clouds.

\section{Semi-direct effect}

To examine the semi-direct effect of BB aerosols, we only use data with a continental tracer concentration greater than 0 to avoid the contrasting meteorological properties between continental air advected over the adjacent ocean and purely marine air masses. In this case, we compare only the differences in cloud properties between continental air with and without BB aerosols. To our knowledge, this is the first time that such a continental tracer is used to isolate purely marine air masses from continental airmasses.

The average GOES cloud fraction over the ocean (Fig. 4) ranges between 0.7 and 0.8 . The cloud fraction is lower near the coast than offshore, because of a lower specific humidity and diminished surface-air temperature contrast. The average GOES cloud albedo is between 0.3 and 0.35 . This average value was calculated using data having a cloud fraction exceeding 0.8 to avoid errors due to broken cloud effects. The average FLEXPART continental tracer within the first kilometer in altitude decreases with distance from shore. The FLEXPART BB tracer concentration within the first km in altitude is greatest south of Los Angeles $\left(9 \mu \mathrm{g} \mathrm{m}^{-3}\right)$, and also decreases with distance from shore. The GFS specific humidity is larger away from the coast while the lower tropospheric stability (LTS; GFS temperature difference between an altitude of $1.5 \mathrm{~km}$ and the surface) decreases with distance from shore. This is probably a consequence of the upwelling which reduces the sea surface temperature (SST) near the coast and then increases the stability of the lower troposphere.

The data are divided according to intervals of humidity, surface temperature and LTS as these are the meteorological factors with the greatest influence on cloud properties (e.g. Kaufman et al., 2005).

To remove the impact of meteorology on the variability of cloud fraction and cloud albedo, the average impact of 


\section{First indirect effect from Biomass Burning}
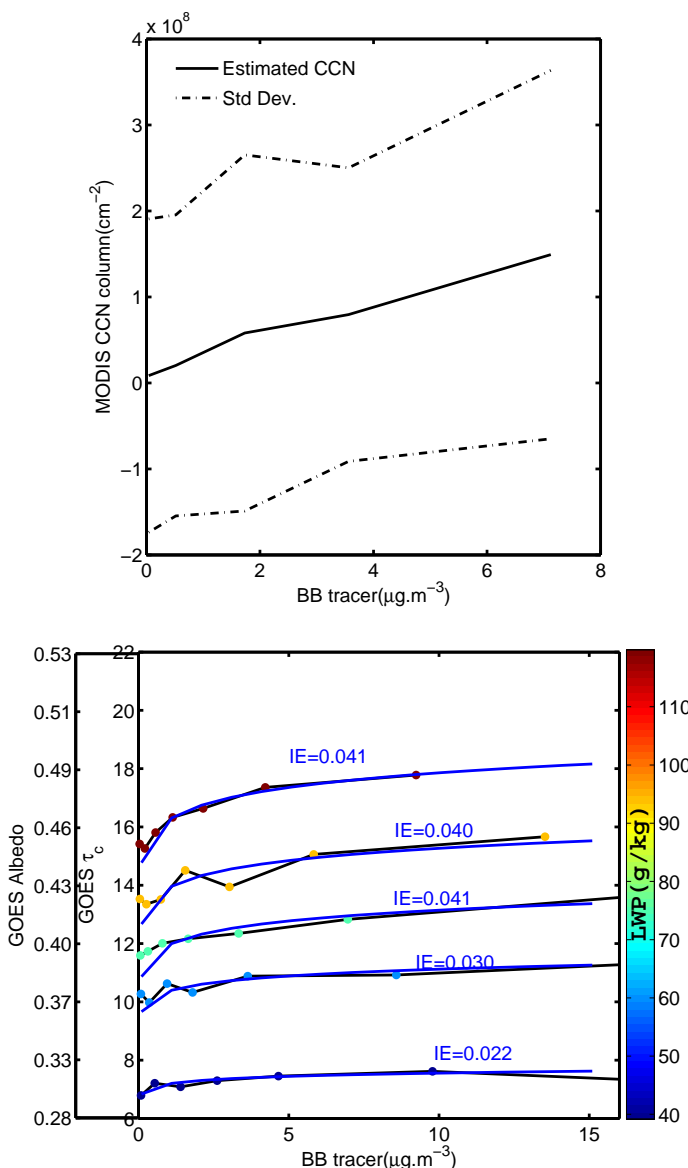

(b)

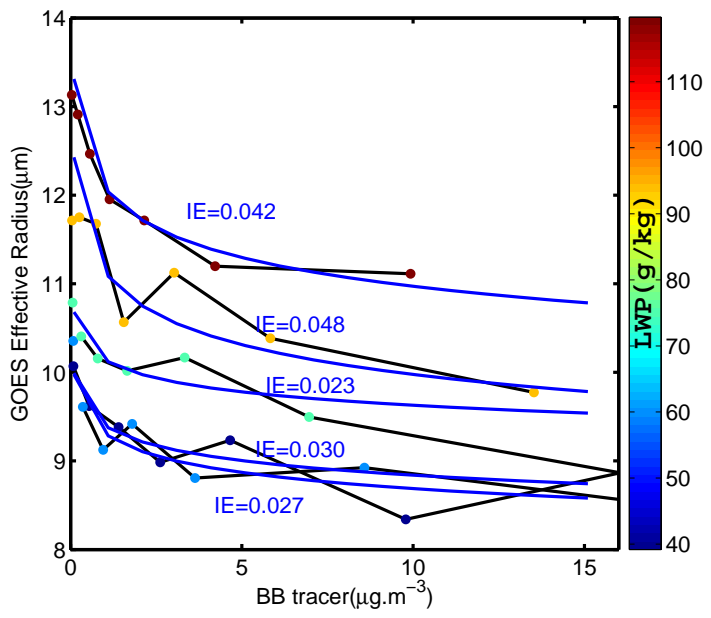

(c)

Fig. 3. (a) Relationship between biomass burning concentration and CCN total column (MODIS product) over the ocean. Relationship between FLEXPART biomass burning tracer concentration and the GOES (b) cloud optical depth or cloud albedo and (c) Effective radius (GOES products) for different Liquid Water Path bins (color scale). The indirect effect index (IE) values of each distribution are shown. The power law fits are shown in blue.

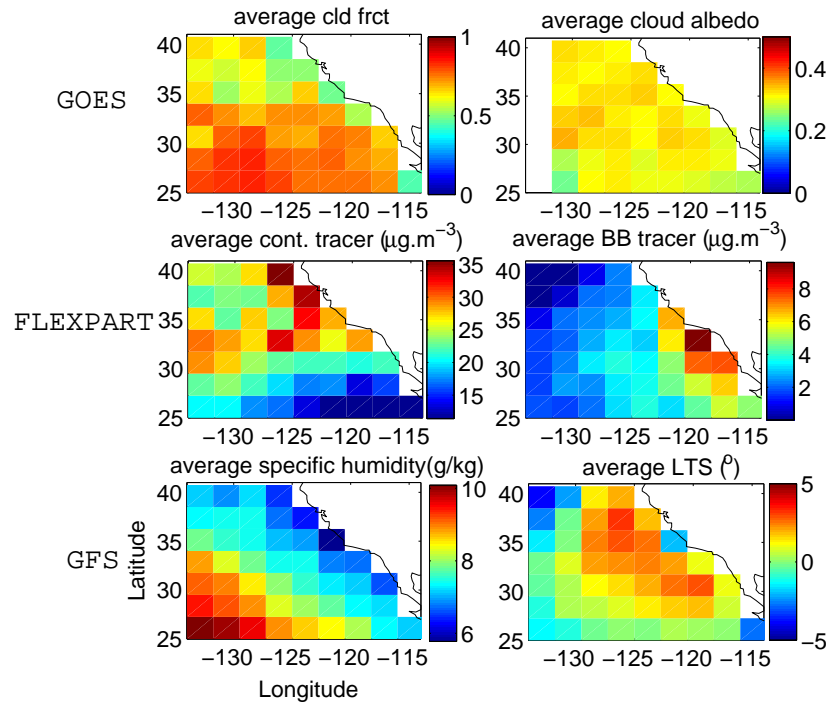

Fig. 4. Maps (deg $\times$ deg) of average cloud fraction, cloud albedo, continental tracer, biomass burning tracer, specific humidity and Lower Tropospheric Stability (LTS) in June and July 2006, 2007 and 2008 .

BB aerosols on the cloud fraction and albedo is calculated in data subdivisions (each representing 1/16 of data) based on intervals of low and high tropospheric stability, humidity, surface temperature, and continental tracer, for each grid cell. Within each grid cell, the median of each distribution is used to separate the data into low and high intervals, so that each of the 16 subdivisions has the same sample size.

To show the robustness of the method, the impact of BB aerosols on cloud fraction and cloud albedo is compared for the subdivisions using continental tracer, high continental tracer only (continental tracer concentration greater than the median), and anthropogenic tracer in place of the continental tracer. The results are shown in Table 1 and will be discussed later.

Figure 5 shows the average cloud fractions when (a) there are no FLEXPART BB aerosols and (b) when there are FLEXPART BB aerosols between the surface and $1 \mathrm{~km}$. The differences between Fig. $5 \mathrm{a}$ and $\mathrm{b}$ are the direct consequence of the presence of $\mathrm{BB}$ tracers.

On average, the cloud fraction is most strongly influenced by the humidity and LTS. The greater the humidity or LTS, the larger the cloud fraction. This is due to the fact that an increase of LTS reinforces the inversion layer, and thus increases the stability of the marine boundary layer, which reduces the vertical entrainment of dry air from above.

It is clear that the higher the surface temperature, the lower the cloud fraction. By increasing the temperature, the relative humidity is reduced. Cloudiness can also reduce surface insolation and hence surface temperature.

Continental tracer tends to be associated with increased cloud fraction. However, it is less evident compared to the 


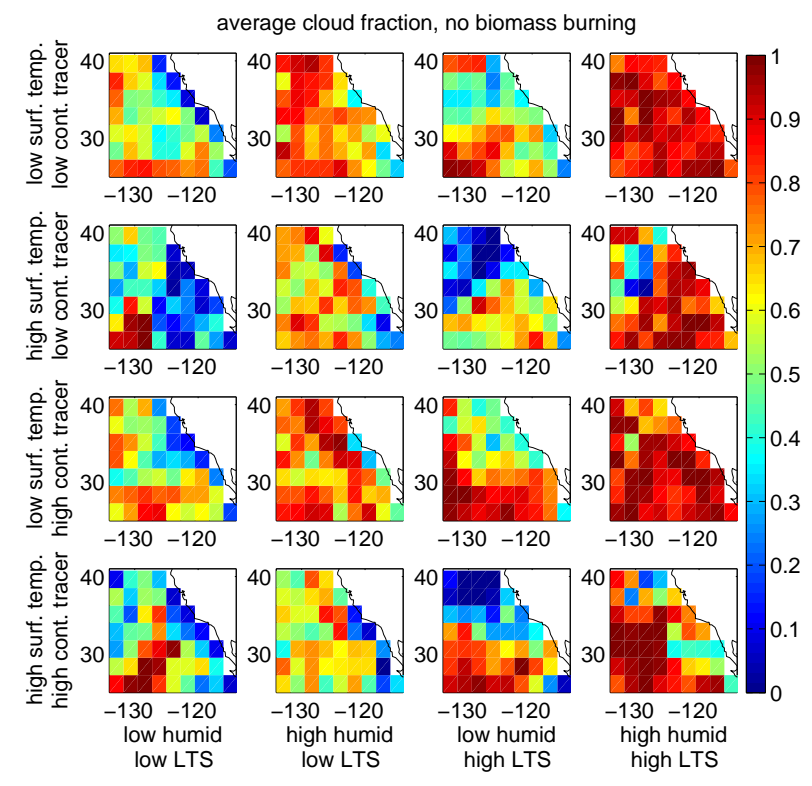

(a)

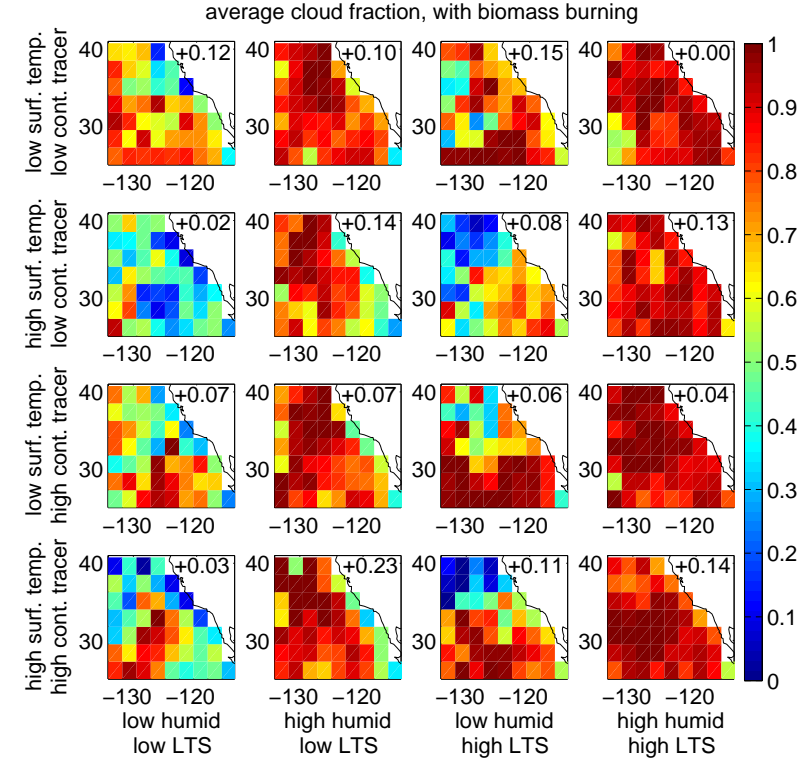

(b)

Fig. 5. Maps (deg $\times$ deg) of average cloud fraction calculated by dividing the data in intervals of LTS and specific humidity (columns), and surface temperature and continental tracer (rows). The average values are calculated when biomass burning tracer (a) is not and (b) is present. The numbers over the continent in (b) indicate the average variation in cloud fraction by subtracting panel (a) from (b).

different meteorological parameters. A higher continental tracer is related to a larger percentage of air coming from the continent, implying different transport patterns or different meteorological situations, but also an increase of biogenic and anthropogenic aerosols.

The overall impact of BB aerosols on cloud fraction over the ocean is positive. On average, the highest impacts of $\mathrm{BB}$ aerosols on cloud are found at high humidity and low

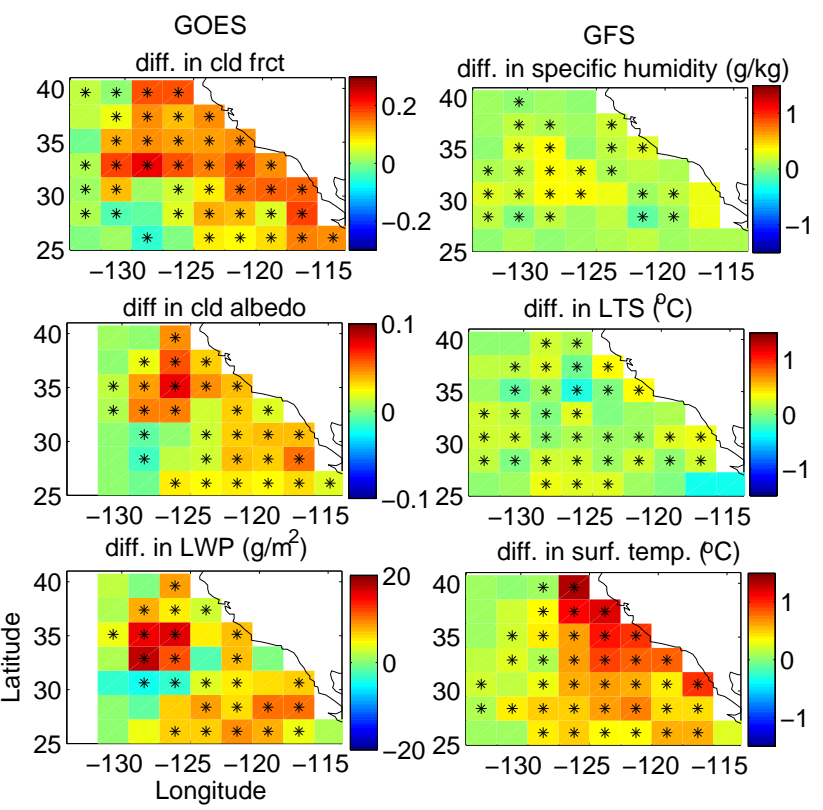

Fig. 6. Maps $(\operatorname{deg} \times \operatorname{deg})$ of average differences in cloud fraction, albedo, LWP $\left(\mathrm{g} / \mathrm{m}^{2}\right)$; specific humidity $(\mathrm{g} / \mathrm{kg})$, LTS $\left({ }^{\circ} \mathrm{C}\right)$ and surface temperature $\left({ }^{\circ} \mathrm{C}\right)$ due to the presence of biomass burning aerosols (e.g. the differences in cloud fraction are the average values of Fig. 5b-Fig 5a). The stars indicate the cells which have a statistically significant difference ( $95 \%$ confidence).

LTS. High humidity promotes greater cloud fraction, and thus larger differences in cloud fraction can occur in the presence of BB aerosols. The fact that the greatest impacts are found at low LTS is probably a sign that the BB aerosols tend to increase the LTS, and thus reduce the vertical entrainment of dry air from above.

We do not expect any influence of BB aerosols on the GFS meteorological parameters used in this study. It is unlikely that the data assimilation in the NCEP GFS model takes into account the thermal radiative impact of the BB plumes, especially over the ocean, because of the sparse in-situ measurements. As a result, it is possible that the vertical distribution of $\mathrm{BB}$ aerosols is less accurate near the marine inversion layer. However, the uncertainty of the tracer's vertical distribution probably does not affect its advection. We do not expect a large differential advection which can compromise our aerosol calculations in grid cells of $2.25 \times 2.25 \mathrm{deg}$. Because we are focusing on the presence or absence of BB aerosols between the surface and $1 \mathrm{~km}$, the uncertainties in the vertical distribution of $\mathrm{BB}$ aerosols have a minor impact on the results.

Figure 6 presents the average differences in cloud fraction $(\Delta f)$, albedo $(\Delta A)$ and LWP due to the presence of $\mathrm{BB}$ aerosols. The grid cells with a significant difference $(95 \%$ confidence) are highlighted by black stars. The meteorological conditions (from NCEP GFS) in terms of LTS, humidity and temperature are the average values shown in Fig. 4. The 
difference in cloud fraction is positive along the coast within a band about $500 \mathrm{~km}$ wide. The values range between +0.1 and +0.25 , with an average value of +0.143 . Further away from the coast, $\Delta f$ is close to zero or negative with values between 0 and -0.05 , with an average value of -0.023 .

$\Delta A$ is also significant. Within the same coastal band, $\Delta A$ is positive, with an increase of +0.02 to +0.1 (average value of +0.038$)$. These values are associated with positive differences in LWP between +5 to $+20 \mathrm{~g} \mathrm{~m}^{-2}$. Further away from the coast, $\Delta A$ is negative, with values of 0 to -0.02 (average value of -0.006), associated with slightly negative differences in LWP values.

These results are not very sensitive to the use of high continental tracer or anthropogenic tracer rather than continental tracer to subdivide the data (see Table 1). Variability in meteorological parameters does not explain the differences in cloud fraction and albedo. The difference in specific humidity is small within the band along the coast, with an average difference value of $+0.15 \mathrm{~g} \mathrm{~kg}^{-1}$ (a slightly higher humidity is associated with the presence of BB aerosols). The difference in LTS is also small. Within the band along the coast, negative and positive values are found, between -0.2 and $+0.2^{\circ} \mathrm{C}$. The difference in surface temperature ranges between 0 and $1{ }^{\circ} \mathrm{C}$ along the coast. The grid cells with significant differences in meteorological parameters are quite rare.

A multivariate regression is applied to calculate the dependence of $f$ and $A$ on specific humidity $(q)$, LTS, surface temperature $\left(T_{s}\right)$, boundary layer height $(\mathrm{BLH})$, continental tracer $\left(C_{\text {cont }}\right)$ and anthropogenic tracer $\left(C_{\text {anthro }}\right)$ using all the data available over the ocean.

To conduct the multivariate regression, the following power law equations are used:

$$
\begin{aligned}
& f=a_{0} \cdot(\mathrm{LTS}+20)^{a_{1}} \cdot \mathrm{BLH}^{a_{2}} \cdot T_{s}^{a_{3}} \cdot q^{a_{4}} \cdot C_{\text {cont }}^{a_{5}} \cdot C_{\text {anthro }}^{a_{6}} \\
& A=b_{0} \cdot(\mathrm{LTS}+20)^{b_{1}} \cdot \mathrm{BLH}^{b_{2}} \cdot T_{s}^{b_{3}} \cdot q^{b_{4}} \cdot C_{\text {cont }}^{b_{5}} \cdot C_{\text {anthro }}^{b_{6}}
\end{aligned}
$$

The results were improved using power law equations rather than linear equations. We applied an offset of $20^{\circ} \mathrm{C}$ on LTS to have positive values only. The results of the multivariate regression on $f$ and $A$ are shown in Fig. 7. A summary of the multivariate regression is shown in Table 2, showing the variations in $f$ and $A$ due to a change from the 5th to 95 th percentile of the average meteorological parameters and aerosols, and the factors used in the multivariate regressions.

The multivariate regression is applied to the average meteorological values found in the presence or absence of $\mathrm{BB}$ aerosols in each grid cell. By subtracting the $f$ and $A$ for these two situations ( $f_{w}, A_{w}$ and $f_{w / o}, A_{w / o}$ respectively), the variation in $f\left(\varepsilon_{f}\right)$ and $A\left(\varepsilon_{A}\right)$ resulting from the variations in meteorological parameters and aerosol burden can be estimated in the 16 different subdivisions:

$\varepsilon_{f}=\frac{1}{16} \sum_{i=1}^{16} f_{w}^{i}-f_{w / o}^{i}$
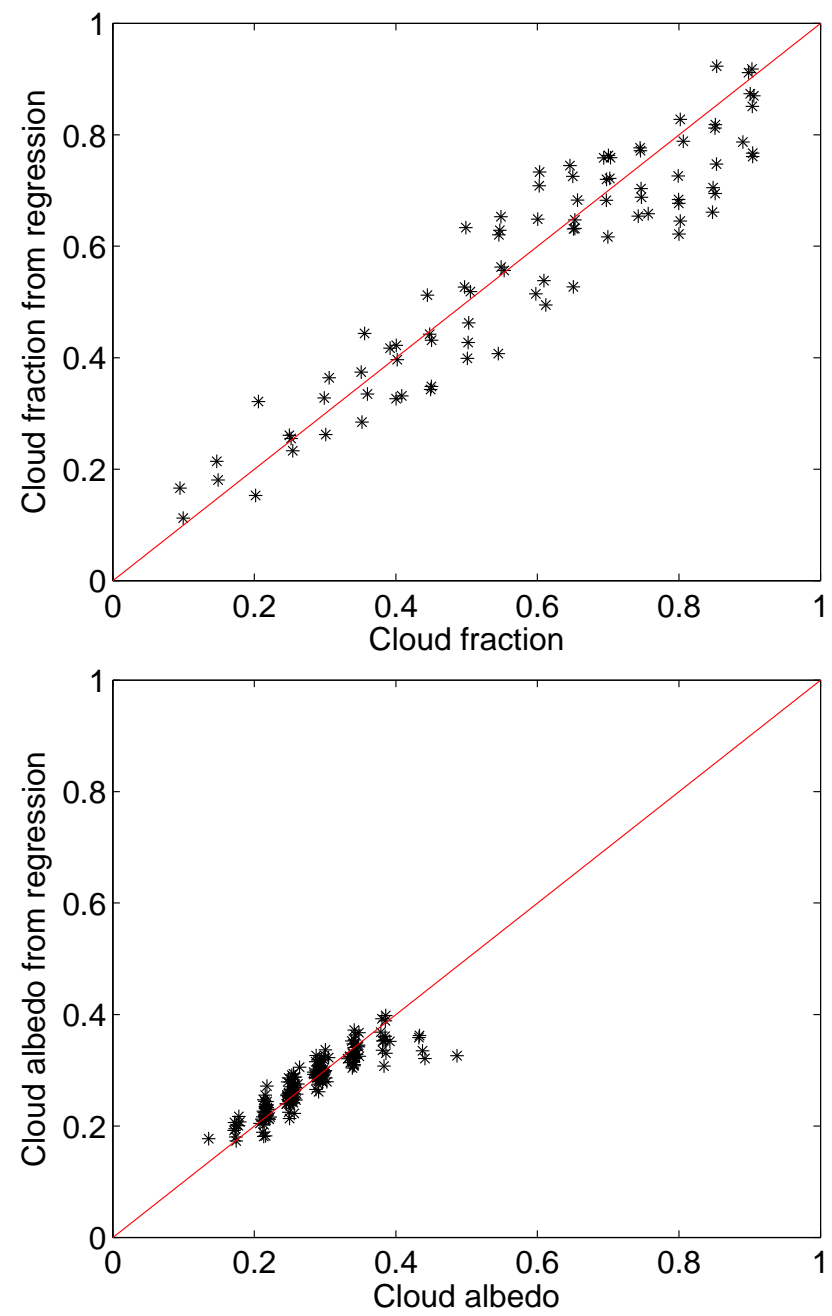

Fig. 7. Results of the multivariate regressions applied on cloud fraction and cloud albedo. Each data point is the average of 50 points in cloud fraction and cloud albedo bins of 0.05 .

$\varepsilon_{A}=\frac{1}{16} \sum_{i=1}^{16} A_{w}^{i}-A_{w / o}^{i}$

Because these variations represent the error inherent to our method of assessing the average differences in cloud fraction $(\Delta f)$ and cloud albedo $(\Delta A)$ due to the presence of $\mathrm{BB}$ aerosols, we call them the biases in the difference in cloud fraction $\left(\varepsilon_{f}\right)$ and cloud albedo $\left(\varepsilon_{A}\right)$ due to the meteorological parameters and non-BB aerosol burden (change in anthropogenic and biogenic aerosols).

Figure 8 shows the bias in the difference in cloud fraction $\varepsilon_{f}$ (top). Within the band along the coast, the overall biases $\varepsilon_{f}$ and $\varepsilon_{A}$ are small. $\varepsilon_{f}$ ranges between -0.04 and +0.03 with an average value of -0.01 (average relative bias $\varepsilon_{f} / \Delta f$ of $-5 \%$ ). $\varepsilon_{A}$ (Fig. 8, bottom) ranges between -0.016 and -0.007 with an average value of -0.01 (average relative bias $\varepsilon_{A} / \Delta A$ of $-37 \%$ ). These results demonstrate that the method 
Table 2. Multivariate regression analysis of the influence of meteorological parameters and aerosols on cloud fraction and cloud albedo. The cloud parameter changes (first 2 columns) are calculated by applying a change from the 5th to 95th precentile of the parameters (rows) used in the multivariate regression (last 2 columns).

\begin{tabular}{lllll}
\hline & $\begin{array}{l}\text { Change in Cloud } \\
\text { fraction }(\Delta f)\end{array}$ & $\begin{array}{l}\text { Change in Cloud } \\
\text { albedo }(\Delta A)\end{array}$ & $\begin{array}{l}\text { Multivariate regression } \\
\text { factors for } f\end{array}$ & $\begin{array}{l}\text { Multivariate regression } \\
\text { factors for } A\end{array}$ \\
\hline continental tracer $\left(+10 \mu \mathrm{g} \mathrm{m}^{-3}\right)$ & +0.04 & +0.082 & +0.06 & +0.23 \\
anthropogenic tracer $\left(+3 \mu \mathrm{g} \mathrm{m}^{-3}\right)$ & +0.03 & +0.05 & +0.07 & +0.20 \\
Surface temperature $\left(+4^{\circ} \mathrm{C}\right)$ & -0.42 & -0.033 & -48.0 & -11.7 \\
specific humidity $(+2 \mathrm{~g} / \mathrm{kg})$ & +0.27 & +0.025 & +2.46 & +0.67 \\
boundary layer height $(+100 \mathrm{~m})$ & -0.02 & -0.042 & -0.17 & -0.38 \\
lower tropospheric stability $\left(+5^{\circ} \mathrm{C}\right)$ & +0.44 & +0.086 & +2.57 & +1.77 \\
\hline
\end{tabular}

Bias on cloud fraction difference

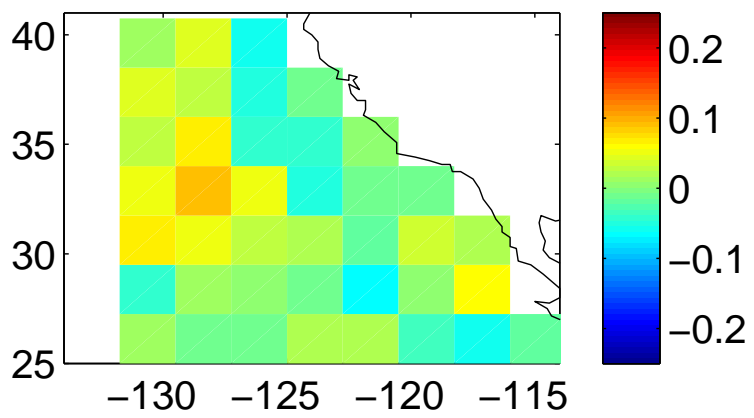

Bias on cloud albedo difference

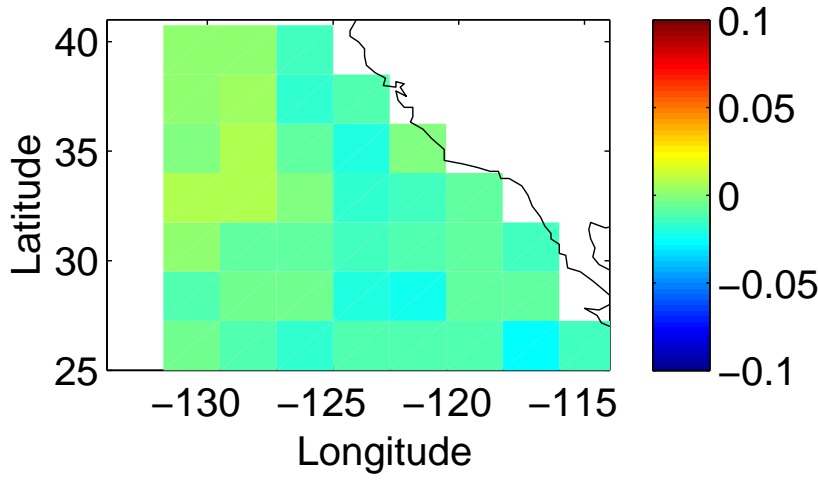

Fig. 8. Maps $(\operatorname{deg} \times \operatorname{deg})$ of biases on cloud fraction and cloud albedo differences (see Fig. 6) due to meteorological parameters and anthropogenic aerosols.

to remove the impact from meteorological parameters and aerosols from our analysis was successful.

Further away from the coast, in the area with negative $\Delta f$, the bias ranges between -0.04 and +0.01 . $\varepsilon_{f}$ is large compared to $\Delta f$ (average relative bias of $48 \%$ ). The average relative bias in cloud albedo is $-70 \% . \varepsilon_{f}$ and $\varepsilon_{A}$ are large in this region, and cannot be neglected.

\section{Discussion}

To estimate the variation in shortwave radiative flux resulting from a change in cloud fraction and cloud albedo due to $\mathrm{BB}$ aerosols (at 14:00 local time), we used the same approach as described in Seinfeld and Pandis (1998). An ocean surface albedo equal to 0 is assumed. Only the first-order radiative effect of clouds is considered here. The outgoing radiative flux at the top of the atmosphere (TOA) $F_{\text {out }}$ is equal to:

$F_{\text {out }}=F_{\text {in }} \cdot T^{2} \cdot f \cdot A$

$F_{\text {in }}$ denotes the incoming flux at the top of the atmosphere, $T$ is the atmospheric transmittance, $f$ is the cloud fraction and $A$ the cloud albedo. $T$ includes the extinction of the atmosphere but also the solar absorption from the BB aerosols. The perturbed outgoing radiative flux due to $\mathrm{BB}$ aerosols indirect effect can be expressed as

$F_{\text {out }}+\Delta F_{\text {out }}=F_{\text {in }} \cdot T^{2} \cdot(f \cdot A+\Delta f \cdot A+f \cdot \Delta A+\Delta f \cdot \Delta A)(7)$

$\Delta f$ and $\Delta A$ denote the changes in cloud fraction and cloud albedo due to the presence of BB aerosols (see Fig. 6 and Sect. 5). Therefore the relative indirect radiative forcing due to $\mathrm{BB}$ aerosols $\delta F(\%)$ can be expressed as

$\delta F=\frac{\Delta F_{\text {out }}}{F_{\text {in }} \cdot T^{2}}=\Delta f \cdot A+f \cdot \Delta A+\Delta f \cdot \Delta A$

A negative sign of $\delta F$ indicates a cooling influence. We calculated also the standard deviation $\left(\sigma_{F}\right.$ assuming Gaussian distributions for $\Delta f$ and $\Delta A)$ and the bias $\left(\varepsilon_{F}\right.$ using $\varepsilon_{f}$ and $\varepsilon_{A}$ rather than $\Delta f$ and $\Delta A$ in equation 8 ) in $\delta F$.

We estimate that the uncertainty associated with the use of continental or anthropogenic tracers to subdivide the data and then study the indirect radiative forcing by BB aerosols is $\pm 0.5 \%$ (Table 1 ).

The BB aerosol has a negative indirect radiative forcing $\delta F$ of up to $-10 \%$ within the $500 \mathrm{~km}$-wide band along the coast at 14:00 local time (Fig. 9). Within this region, the average value of $\delta F$ is $-7.5 \%$ ( $-7.5 \%$ using the cloud fraction 


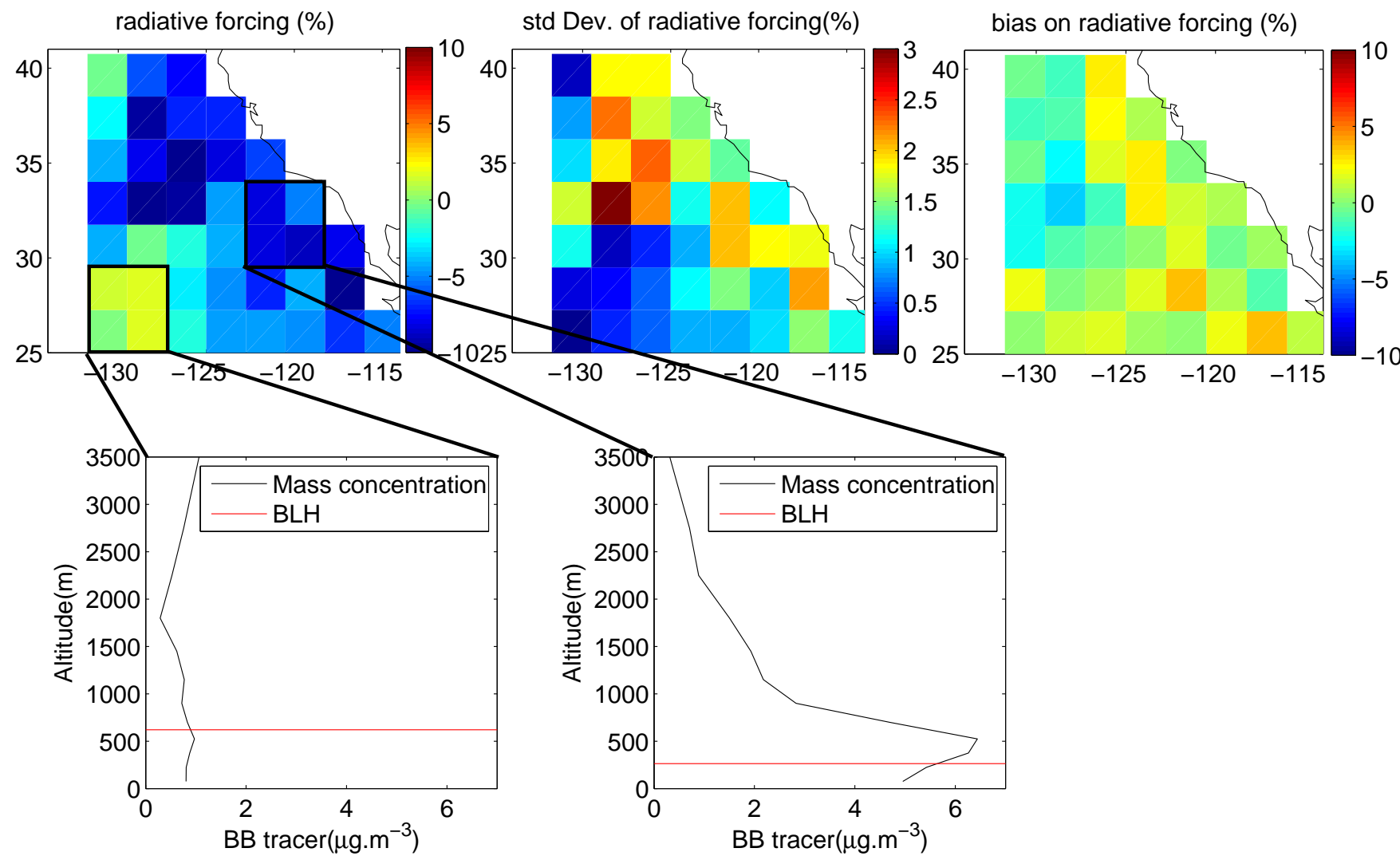

Fig. 9. Maps (deg $\times$ deg) of average value, standard deviation and bias of the indirect radiative forcing due to biomass burning aerosol (negative values denote a cooling effect). The average vertical distributions of biomass burning tracer concentration in two different regions is also shown.

calculated with the visible channel) with a standard deviation $\sigma_{F}$ of $1.7 \%$ (1.8\% using visible channel) and an average bias due to meteorological parameters and aerosols $\varepsilon_{F}$ of $+0.9 \%$. The similar results using two different methods to compute the cloud fraction confirm the robustness of the cloud fraction calculations.

Using high continental or anthropogenic tracers to subdivide the data (Table 1) also gives similar results, with average values of $-6.9 \%$ and $-7.8 \%$ respectively, which fall within the range of the standard deviation.

The average vertical distribution of $\mathrm{BB}$ tracer shows a maximum of $6 \mu \mathrm{g} \mathrm{m}^{-3}$ above the marine boundary layer within the region near the coast (Fig. 9). The presence of $\mathrm{BB}$ aerosols presumably increases the temperature of the local air mass by absorbing solar energy and converting it into thermal energy. Johnson et al. (2004) have shown that this process increases the static stability and reduces the vertical entrainment of dry air and absorbing aerosols. It has been shown that within this region, the BB aerosols increase the cloud fraction, cloud albedo and LWP. FLEXPART suggests that a significant quantity of absorbing aerosols are also located in the marine boundary layer $\left(4 \mu \mathrm{g} \mathrm{m}^{-3}\right)$. It is possible that FLEXPART overestimates the number of aerosols within the marine BL near the coast. FLEXPART is not a meso- scale model, and cannot fully resolve the marine inversion layer, or apply any feedback on the temperature of the air mass due to the transport of aerosols. The temperature of the air masses above the marine BL is probably underestimated and thus the vertical entrainment through the marine $\mathrm{BL}$ is overestimated in the model, which explains the significant quantity of aerosols in the marine boundary layer.

Further offshore, the indirect radiative forcing $\delta F$ by BB aerosols is slightly positive with values up to $+2 \%$. The average impact is $+1.3 \%$, with a standard deviation $\sigma_{F}$ of $0.3 \%$ and a bias $\varepsilon_{F}$ of $+0.5 \%$ The standard deviation and the bias are small compared to the average value indicating that the positive impact of $\mathrm{BB}$ aerosols in this region is statistically significant. Using the high continental or anthropogenic tracer to subdivide the data (Table 1), the average values are $+0.8 \%$ and $+1.7 \%$ respectively.

According to FLEXPART, the average vertical distribution of $\mathrm{BB}$ aerosols in this region differs from the near-shore profile, with a relatively constant profile between the surface and $1.2 \mathrm{~km}$ of $1 \mu \mathrm{g} \mathrm{m}^{-3}$ of BB aerosol. The concentration is 6 times smaller than what is found near the coast. Away from the coast, the MBL is deeper because the sea surface temperature is higher. Therefore the temperature inversion layer is weaker, which increases the entrainment of air from above. 


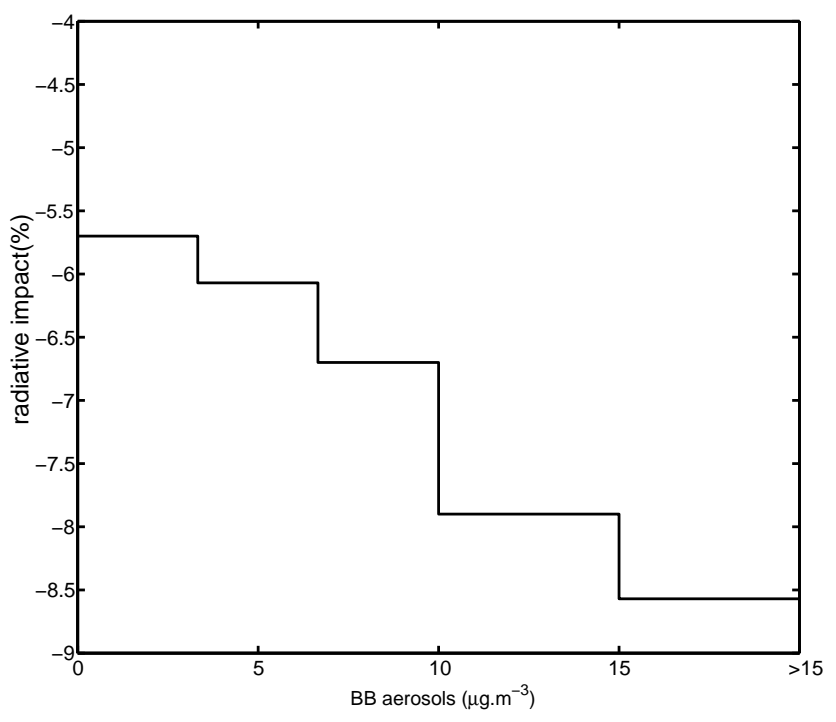

Fig. 10. Average values of the indirect radiative forcing due to biomass burning aerosols in a 500-km band along the coast of California based on 5 intervals of biomass burning tracer concentration in the $0-1 \mathrm{~km}$ altitude range, during (average concentration $\left.6.4 \mu \mathrm{g} \mathrm{m}^{-3}\right), 2007\left(5.9 \mu \mathrm{g} \mathrm{m}^{-3}\right)$ and $2008\left(11 \mu \mathrm{g} \mathrm{m}^{-3}\right)$.

The BB aerosols can potentially increase the temperature in the MBL, reduce the relative humidity and thus reduce the cloud fraction.

Between the surface and $1 \mathrm{~km}$, the BB aerosol concentration was $4 \%$ smaller in 2007 than in 2006, and 66\% higher in 2008 than in 2006. We attempted to relate the indirect radiative forcing due to $\mathrm{BB}$ aerosols within the region along the coast to the difference in BB emissions over the 3-year time period. Figure 10 presents the indirect radiative forcing in intervals of $\mathrm{BB}$ aerosol concentration in the first kilometer of the atmosphere during 2006, 2007 and 2008. The average concentrations of BB aerosols were $6.4 \mu \mathrm{g} \mathrm{m}^{-3}$ in 2006, $5.9 \mu \mathrm{g} \mathrm{m}^{-3}$ in 2007 and $11 \mu \mathrm{g} \mathrm{m}^{-3}$ in 2008. The percentage of offshore continental airmass in the presence of BB aerosols was $60 \%$ in 2006, 39\% in 2007 and 59\% in 2008. The lowest BB aerosol concentration bin (lower than $3.3 \mu \mathrm{g} \mathrm{m}^{-3}$ ) is associated with an indirect radiative forcing of $-5.7 \% \pm 1.3 \%$ and was most common in 2006 (contribution of $45 \%$ ). For the highest BB concentrations bin (higher than $15 \mu \mathrm{g} \mathrm{m}^{-3}$ ), the average indirect radiative forcing is $-8.6 \%$ $\pm 2.0 \%$, and occurred most frequently in 2008 (contribution of $57 \%$ ).

These results imply that an increase in BB concentration increases the heating of the air mass above the inversion layer, increases the strength of the inversion layer and reduces the vertical entrainment of dry air and absorbing aerosols. The results also show that BB aerosols in 2008 had a greater impact on indirect radiative forcing than 2006, because of larger emissions of BB aerosols.

\section{Conclusions}

Satellite products from GOES and MODIS and biomass burning aerosol calculations from FLEXPART are used to assess the biomass burning aerosol indirect effect on marine stratocumulus clouds west of California at 14:00 local time in June and July 2006, 2007 and 2008.

A novel aspect of our analysis is the use of a continental tracer to segregate the data according to air mass origin and the associated differences in meteorology. We focused on biomass burning aerosol rather than anthropogenic aerosol because the high variability in biomass burning aerosol allowed us to clearly study the impact of continental air on marine stratocumulus clouds in the presence or absence of biomass burning aerosols. A similar analysis could not have been easily done with anthropogenic aerosols, which are always present in the continental air masses of the western USA.

A study of the first indirect effect from biomass burning aerosols was conducted at constant liquid water path (LWP). The indirect effect index (IE) values based on the relationship between cloud optical thickness or effective radius and biomass burning aerosol concentration ranged between 0.02 and 0.04 , depending on the LWP value. These values are relatively small, perhaps because of the low hygroscopicity of the biomass burning aerosols or because the cloud and aerosol interaction are studied over a large spatial scale (McComiskey et al., 2009).

Biomass burning aerosols increased the cloud fraction within a $500 \mathrm{~km}$-band along the coast by +0.143 , and the cloud albedo by +0.038 , resulting in an indirect radiative forcing of $-7.5 \% \pm 1.7 \%$ (cooling). The bias from meteorology is $+0.9 \%$ which means that the average result is slightly underestimated. This region has an average vertical distribution of biomass burning aerosols that maximizes above the inversion layer. The semi-direct effect from biomass burning aerosols appears to increase the lower tropospheric stability, reducing the vertical entrainment of dry air and absorbing aerosols into marine stratocumulus clouds, promoting shallow cloud maintenance.

Away from the coast, biomass burning aerosols reduce the cloud fraction by -0.023 , and reduce the cloud albedo by -0.006 , resulting in an indirect radiative forcing of $+1.3 \%$ $\pm 0.3 \%$. The bias from meteorological parameters is $+0.5 \%$. Even though the average impact of biomass burning aerosols is relatively small, it is statistically significant. The vertical distribution of biomass burning aerosols shows a maximum within the marine boundary layer. In this region, the absorbing aerosols warm the air masses in the marine boundary layer via the semi-direct effect, reducing the relative humidity and cloud cover.

Future analyses need to include a study of the biomass burning aerosol indirect effect throughout the rest of the day to fully quantify its impact on the radiative balance of the eastern North Pacific Ocean. Improvements in constraining 
the calculated impact of biomass burning aerosols on cloud fraction and albedo would benefit from ship or aircraft based in situ and lidar measurements of biomass burning aerosols in the marine boundary layer.

Biomass burning is influenced by moisture and surface winds, with warmer and drier conditions increasing the likelihood of biomass burning (Westerling et al., 2006). According to the IPCC (2007), California will have an increase in surface temperature and a decrease of humidity as a result of climate change. If warmer and drier conditions lead to increased biomass burning in the future, our study implies a higher likelihood of biomass burning aerosols, increasing marine stratocumulus cloud cover and albedo, which would constitute a local negative feedback.

Acknowledgements. This work was supported in part by NOAA's Climate Goal Program. The GOES cloud property retrievals were supported by the NASA Applied Sciences Program and the Department of Energy ARM Program through DE-AI0207ER64546. Graham Feingold was supported by NOAA's Climate Goal Program.

Edietd by: J. Quaas

\section{References}

Andreae, M. O., Rosenfeld, D., Artaxo, P., Costa, A. A., Frank, G. P., Longo, K. M., and Silvas-Dias, M. A. F.: Smoking rain clouds over the Amazon, Science, 303, 1337-1342, doi:10.1126/science.1092779, 2004.

Albrecht, B. A., Penc, R. S., and Schubert, W. H.: An observational study of cloud-topped mixed layers, J. Atmos. Sci., 42(8), 800$822,1985$.

Avey, L., Garrett, T. J., and Stohl, A.: Evaluation of the aerosol indirect effect using satellite, tracer transport model, and aircraft data from the International Consortium for Atmospheric Research on Transport and Transformation, J. Geophys. Res., 112, D10S33, doi:10.1029/2006JD007581, 2007.

Bréon, F.-M., Tanr, D., and Generoso, S.:Aerosol effect on cloud droplet size monitored from satellite, Science 295 , 834-838, doi:10.1126/science.1066434, 2002

Bretherton, C. S., Blossey, P. N., and Uchida, J.: Cloud droplet sedimentation, entrainment efficiency, and subtropical stratocumulus albedo, Geophys. Res. Lett., 34, L03813, doi:10.1029/2006GL027648, 2007.

Brioude, J., Cooper, O. R., Trainer, M., Ryerson, T. B., Holloway, J. S., Baynard, T., Peischl, J., Warneke, C., Neuman, J. A., De Gouw, J., Stohl, A., Eckhardt, S., Frost, G. J., McKeen, S. A., Hsie, E.-Y., Fehsenfeld, F. C., and Nédélec, P.: Mixing between a stratospheric intrusion and a biomass burning plume, Atmos. Chem. Phys., 7, 4229-4235, 2007, http://www.atmos-chem-phys.net/7/4229/2007/.

Chameides, W., Luo, C., Saylor, R., Streets, D., Huang, Y., Bergin, M., and Giorgi, F.: Correlation between model-calculated anthropogenic aerosols and satellite-derived cloud optical depths: Indication of indirect effect?, J. Geophys. Res., 107(D10), 4085, doi:10.1029/2000JD000208, 2002.
Feingold, G., Stevens, B., Cotton, W. R., and Walko, R. L.: An explicit microphysics/LES model designed to simulate the Twomey Effect, Atmos. Res., 33, 207-233, 1994.

Feingold, G., Remer, L. A., Ramaprasad, J., and Kaufman, Y. J.: Analysis of smoke impact on clouds in Brazilian biomass burning regions: An extension of Twomey's approach, J. Geophys. Res., 106(D19), 22907-22922, 2001.

Feingold, G., Eberhard, W. L., Lane, D. E., and Previdi, M.: First measurements of the Twomey aerosol indirect effect using ground-based remote sensors, Geophys. Res. Lett., 30(6), 1287, doi:10.1029/2002GL016633, 2003.

Feingold, G., Jiang, H., and Harrington, J. Y.: On smoke suppression of clouds in Amazonia, Geophys. Res. Lett., 32, L02804, doi:10.1029/2004GL021369, 2005.

Forster, C., Stohl, A., and Seibert, P.: Parameterization of convective transport in a Lagrangian particle dispersion model and its evaluation, J. Appl. Meteor. Clim, 46, 403-422, doi:10.1175/JAM2470.1, 2007.

Freeborn, P. H., Wooster, M. J., Hao, W. M., Ryan, C. A., Nordgren, B. L., Baker, S. P., and Ichoku, C.: Relationships between energy release, fuel mass loss, and trace gas and aerosol emissions during laboratory biomass fires, J. Geophys. Res., 113, D01301, doi:10.1029/2007JD008679, 2008.

Freitas, S., Longo, K., Silva Dias, M., Silva Dias, P., Chatfield, R., Prins, E., Artaxo, P., Grell, G., and Recuero, F.: Monitoring the transport of biomass burning emissions in South America, Environ. Fluid Mech., 5(1-2), 135-167, doi:10.1007/s10652-0050243-7, 2005.

Freitas, S. R., Longo, K. M., Chatfield, R., Latham, D., Silva Dias, M. A. F., Andreae, M. O., Prins, E., Santos, J. C., Gielow, R., and Carvalho Jr., J. A.: Including the sub-grid scale plume rise of vegetation fires in low resolution atmospheric transport models, Atmos. Chem. Phys., 7, 3385-3398, 2007,

http://www.atmos-chem-phys.net/7/3385/2007/.

Frost, G. J., McKeen, S. A., Trainer, M., et al.: Effects of changing power plant $\mathrm{NO}_{\mathrm{x}}$ emissions on ozone in the eastern United States: Proof of concept, J. Geophys. Res., 111, D12306, doi:10.1029/2005JD006354, 2006.

Hoffman, W. A., Schroeder, W., and Jackson, R. B.: Positive feedbacks of fire, climate, and vegetation and the conversion of tropical savanna, Geophys. Res. Lett., 29(23), 2087, doi:10.1029/2002GL016021, 2002.

Huffman, G. J., Adler, R. F., Bolvin, D. T., Gu, G., Nelkin, E. J., Bowman, K. P., Hong, Y., Stocker, E. F., and Wolff, D. B.: The TRMM Multi-satellite Precipitation Analysis: QuasiGlobal, Multi-Year, Combined-Sensor Precipitation Estimates at Fine Scale, J. Hydrometeorol., 8(1), 38-55, 2007.

Intergovernmental Panel on Climate Change (IPCC): Climate Change: The Scientfic Basis, Cambridge University Press, UK, 2001, 14296, 2007.

Jedlovec, G. J. and Laws, K.: GOES cloud detection at the Global Hydrology and Climate Center. Preprints, 12th Conference on Satellite Meteorology and Oceanography, Long Beach, CA, USA, Am. Meteor. Soc., P1.21, 2003.

Jensen, M. P., Vogelmann, A. M., Collins, W. D., Zhang, G. J., and Luke, E. P.: Investigation of Regional and Seasonal Variations in Marine Boundary Layer Cloud Properties from MODIS Observations, J. Climate, 21, 4955-4973, doi:10.1175/2008JCLI1974.1, 2008. 
Jiang, H., Xue, H., Teller, A., Feingold, G., and Levin, Z.: Aerosol effects on the lifetime of shallow cumulus, Geophys. Res. Lett., 33, L14806, doi:10.1029/2006GL026024, 2006.

Jin, M. L., Shepherd, J. M., and King, M. D.: Urban aerosols and their variations with clouds and rainfall: a case study for New York and Houston, J. Geophys. Res., 110, D10S20, doi:10.1029/2004JD005081, 2005.

Johnson, B. T., Shine, K. P., and Forster, P. M.: The semidirect aerosol effect: Impact of absorbing aerosols on marine stratocumulus, Q. J. Roy. Meteor. Soc., 30, 1407-1422, doi:10.1256/qj.03.61, 2004.

Kahn, R. A., Li, W.-H., Moroney, C., Diner, D. J., Martonchik, J. V., and Fishbein, E.: Aerosol source plume physical characteristics from space-based multiangle imaging, J. Geophys. Res., 112, D11205, doi:10.1029/2006JD007647, 2007.

Kahn, R. A., Chen, Y., Nelson, D. L., Leung, F.-Y., Li, Q., Diner, D. J., and Logan, J. A.: Wildfire smoke injection heights: Two perspectives from space, Geophys. Res. Lett., 35, L04809, doi:10.1029/2007GL032165, 2008.

Kato, S., Hinkelman, L. M., and Cheng, A.: Estimate of satellitederived cloud optical thickness and effective radius errors and their effect on computed domain-averaged irradiances, J. Geophys. Res., 111, D17201, doi:10.1029/2005JD006668, 2006.

Kaufman, Y. J., Koren, I., Remer, L. A., Rosenfeld, D., and Rudich, Y.: The effect of smoke, dust, and pollution aerosol on shallow cloud development over the Atlantic Ocean, Proc. Natl. Acad. Sci. USA, 102(32), 11207-11212, 2005.

Khain, A. P., Rosenfeld, D., and Pokrovsky, A.: Simulating convective clouds with sustained supercooled liquid water down to $-37.5279 \mathrm{C}$ using a spectral microphysics model, Geophys. Res. Lett., 28, 3887-3890, 2001

Klein, S. A. and Hartmann, D. L.: The seasonal cycle of low stratiform clouds, J. Climate, 6, 1588-1606, 1993.

Kogan, Y. L., Khairoutdinov, M. P., Lilly, D. K., Kogan, Z. N., and Liu, Q.: Modeling of stratocumulus cloud layers in a large eddy simulation model with explicit microphysics, J. Atmos. Sci., 52, 2923-2940, 1995

Koren, I., Kaufman, Y. J., Rosenfeld, D., Remer, L. A., and Rudich, Y.: Aerosol invigoration and restructuring of Atlantic convective clouds, Geophys. Res. Lett., 32, L14828, doi:10.1029/2005GL023187, 2005.

Lohmann, U. and Feichter, J.: Can the direct and semi-direct aerosol effect compete with the indirect effect on a global scale?, Geophys. Res. Lett., 28, 159-161, 2001.

Lu, M.-L. and Seinfeld, J. H.: Study of the Aerosol Indirect Effect by Large-Eddy Simulation of Marine Stratocumulus,J. Atmos. Sci., 62, 3909-3932, 2005.

McComiskey, A. and Feingold, G.: Quantifying error in the radiative forcing of the first aerosol indirect effect, Geophys. Res. Lett., 35, L02810, doi:10.1029/2007GL032667, 2008.

McComiskey, A., Feingold, G., Frisch, A. S., Turner, D. D., Miller, M. A., Chiu, J. C., Min, Q., and Ogren, J. A.: An assessment of aerosol-cloud interactions in marine stratus clouds based on surface remote sensing, J. Geophys. Res., 114, D09203, doi:10.1029/2008JD011006, 2009.

McKeen, S. A., Wotawa, G., Parrish, D. D., Holloway, J. S., Buhr, M. P., Hubler, G., Fehsenfeld, F. C., and Meagher, J. F.: Ozone production from Canadian wildfires during June and July of 1995, J. Geophys. Res., 107(D14), 4192,
doi:10.1029/2001JD000697, 2002.

Medeiros, B., Stevens, B., Held, I. M., Zhao, M., Williamson, D. L., Olson, J. G., and Bretherton, C. S.: Aquaplanets, Climate Sensitivity, and Low Clouds, J. Climate, 21, 4974-4991, doi:10.1175/2008JCLI1995.1, 2008.

Minnis, P., Nguyen, L., Smith Jr., W. L., Khaiyer, M. M., Palikonda, R., Spangenberg, D. A., Doelling, D. R., Phan, D., Nowicki, G. D., Heck, P. W., and Wolff, C.: Real-time cloud, radiation, and aircraft icing parameters from GOES over the USA, Proc. 13th AMS Conf. Satellite Oceanogr. and Meteorol., Norfolk, VA, USA, 20-24 September, CD-ROM, P7.1, 2004.

Minnis, P., Nguyen, L., Doelling, D. R., Young, D. F., Miller, W. F., and Kratz, D. P.: Rapid calibration of operational and research meteorological satellite imagers, Part I: Evaluation of research satellite visible channels as references, J. Atmos. Oceanic Technol., 19, 1233-1249, 2002.

Minnis, P., Sun-Mack, S., Young, D. F., Heck, P. W., Garber, D. P., et al.: Cloud property retrieval techniques for CERES using TRMM VIRS and Terra and Aqua MODIS data, IEEE T. Geosci. Remote Sens., submitted, 2009.

Platnick, S. and Twomey, S.: Determining the susceptibility of cloud albedo to changes in droplet concentration with the advanced very high resolution radiometer, J. Appl. Meteorol., 33, 334-347, 1993.

Prins, E., Feltz, J., Menzel, W., and Ward, D.: An overview of GOES-8 diurnal fire and smoke results for SCAR-B and 1995 fire season in South America, J. Geophys. Res., 103(D24), 3182131835, 1998.

Randall, D. A., Coakley, J. A., Fairall, C. W., Kropfli, R. A., and Lenschow, D. H.: Outlook for research on subtropical marine stratiform clouds, B. Am. Meteor. Soc., 65, 1290-1301, 1984.

Remer, L. A., Kaufman, Y. J., Tanré, D., et al.: The MODIS aerosol algorithm, products and validation, J. Atmos. Sci., 62, 947-973, 2005.

Rosenfeld, D.: Suppression of rain and snow by urban and industrial air pollution, Science, 287, 1793-1796, 2000.

Seinfeld, J. H. and Pandis, S. N.: Atmospheric chemistry and physics: From air pollution to climate change, John Wiley \& Sons, Inc., New York, USA, 1998.

Sharon, T. M., Albrecht, B. A., Jonsson, H. H., Minnis, P., Khaiyer, M. M., Van Reken, T. M., Seinfeld, J., and Flagan, R.: Aerosol and cloud microphysical characteristics of rifts and gradients in maritime stratocumulus clouds, J. Atmos. Sci., 63, 983-997, 2006.

Schwartz, S. E., Harshvardham, and Benkovitz, C. M.: Influence of anthropogenic aerosol on cloud optical depth and albedo shown by satellite measurements and chemical transport modeling, Proc. Natl. Acad. Sci. USA, 99, 1784-1789, 2002.

Stohl, A. and Thomson, D. J.: A density correction for Lagrangian particle dispersion models, Bound.-Lay. Meteorol., 90, 155-167, 1999.

Stohl, A., Forster, C., Frank, A., Seibert, P., and Wotawa, G.: Technical note: The Lagrangian particle dispersion model FLEXPART version 6.2, Atmos. Chem. Phys., 5, 2461-2474, 2005, http://www.atmos-chem-phys.net/5/2461/2005/.

Stohl, A., Berg, T., Burkhart, J. F., Fjǽraa, A. M., Forster, C., Herber, A., Hov, Ø., Lunder, C., McMillan, W. W., Oltmans, S., Shiobara, M., Simpson, D., Solberg, S., Stebel, K., Ström, J., Tørseth, K., Treffeisen, R., Virkkunen, K., and Yttri, K. E.: Arc- 
tic smoke - record high air pollution levels in the European Arctic due to agricultural fires in Eastern Europe in spring 2006, Atmos. Chem. Phys., 7, 511-534, 2007, http://www.atmos-chem-phys.net/7/511/2007/.

Treffeisen, R., Tunved, P., Ström, J., Herber, A., Bareiss, J., Helbig, A., Stone, R. S., Hoyningen-Huene, W., Krejci, R., Stohl, A., and Neuber, R.: Arctic smoke - aerosol characteristics during a record smoke event in the European Arctic and its radiative impact, Atmos. Chem. Phys., 7, 3035-3053, 2007, http://www.atmos-chem-phys.net/7/3035/2007/.

Twomey, S. and T. A. Wojciechowski: Observations of the geographical variation of cloud nuclei, J. Atmos. Sci., 26, 684-688, 1969.

Twomey, S.: The influence of pollution on the short wave albedo of clouds, J. Atmos. Sci., 34, 1149-1152, 1977.

Vogelezang, D. H. P. and Holtslag, A. A. M.: Evaluation and model impacts of alternative boundary-layer height formulations, Bound.-Lay. Meteorol., 81, 245-269, 1996.

Warneke, C., Bahreini, R., Brioude, J., et al.: Biomass burning in Siberia and Kazakhstan as an important source for haze over the Alaskan Arctic in April 2008, Geophys. Res. Lett., 36, L02813, doi:10.1029/2008GL036194, 2009.
Westerling, A. L., Hidalgo, H. G., Cayan, D. R., and Swetnam, T. W.: Warming and earlier spring increase Western U. S. forest wildfire activity, Science, 313, 940-943, doi:10.1126/science.1128834, 2006.

Wiedinmyer, C., Quayle, B., Geron, C., Belote, A., McKenzie, D., Zhang, X., Oneill, S., and Wynne, K. K.: Estimating emissions from fires in North America for air quality modeling, Atmos. Env., 40, 3419-3432, doi:10.1016/j.atmosenv.2006.02.010, 2006.

Wilcox, E. M., Harshvardhan, and Platnick, S.: Estimate of the impact of absorbing aerosol over cloud on the MODIS retrievals of cloud optical thickness and effective radius using two independent retrievals of liquid water path, J. Geophys. Res., 114, D05210, doi:10.1029/2008JD010589, 2009.

Wooster, M. J., Roberts, G., Perry, G. L. W., and Kaufman, Y. J.: Retrieval of biomass combustion rates and totals from fire radiative power observations: FRP derivation and calibration relationships between biomass consumption and fire radiative energy release, J. Geophys. Res., 110, D24311, doi:10.1029/2005JD006318, 2005. 